\title{
MODEL PENINGKATAN KINERJA SUMBER DAYA MANUSIA BERBASIS KOMITMEN NORMATIF MELALUI KEPEMIMPINAN DAN TRUST (Studi Pada Guru SLTP Distrik ' $X$ ' Provinsi Papua Barat)
}

\author{
Reijeng Tabara \\ Dosen Program Studi Manajemen Universitas Nani Bili Nusantara Sorong \\ regentabara@gmail.com,
}

\begin{abstract}
ABSTRAK
Konsekuensi logis dari hadirnya Otonomi Khusus daerah Papua di era globalisasi seperti sekarang adalah menuntut terciptanya sumber daya manusia yang berkualitas. Realita Peningkatan kualitas sumber daya manusia menekankan pada penguasaan Iptek dan skill yang membawa konsekuensi untuk mencapai tujuan pembangunan. Salah satu wahana untuk meningkatkan kualitas sumber daya manusia tersebut adalah Pendidikan hampir tidak terjamah. Penelitian ini dilakukan untuk mengetahui Model Peningkatan Kinerja SDM berbasis Komitmen Normatif melalui Kepemimpinan dan Trust. Penelitian ini merupakan jenis explanatory research. Responden dalam penelitian ini adalah Guru SLTP di Distrik X Provinsi Papua barat sebanyak 100 orang. Pengambilan sampel menggunakan teknik purposive sampling. Penelitian dilakukan dengan metode membagikan kuesioner kepada para responden. Analisis data menggunakan regresi linear berganda dengan aplikasi smartPLS versi 2.0 M3. Hasil penelitian menunjukan bahwa Kepemimpinan berpengaruh terhadap kinerja sumber daya manusia, Kepemimpinan berpengaruh terhadap Komitmen Normatif, Trust berpengaruh terhadap kinerja sumber daya manusia, Trust berpengaruh terhadap Komitmen Normatif, Komitmen Normatif berpengaruh terhadap kinerja sumber daya manusia.
\end{abstract}

Kata Kunci: Kepemimpinan, Trust, komitmen Normatif, kinerja sumber daya manusia

ABSTRACT
The logical consequence of the presence Special Autonomy of the Papua region in the current era globalization is demanding the creation qualified human resources. Reality Improving the quality of human resources emphasizes the mastery of science and technology and skills that bring consequences to achieve development goals. One of the rides to improve the quality of human resources is Education is almost untouched. This research is an explanatory research. The respondent of this study were 100 teachers of district $\mathrm{X}$ junior high school in west papua province, using purposive sampling technique. This research was conducted by distributing questionnaires to respondent. Data analysis used multiple linear regression with smart PLS application version 2.0M3. the result of this study Are leadership influence the performance of human resources, leadership influence normative comittmen, trust influence the performance of human resources, trust influence normative commitment, normative commitment influence the performance of human resources.

Keywords: Leadership, Trust, Normative Comittment, and Performance of Human resources 


\section{PENDAHULUAN}

Konsekuensi logis dari hadirnya Otonomi Khusus daerah Papua di era globalisasi seperti sekarang adalah menuntut terciptanya sumber daya manusia yang berkualitas. Realita Peningkatan kualitas sumber daya manusia menekankan pada penguasaan Iptek dan skill yang membawa konsekuensi untuk mencapai tujuan pembangunan. Salah satu wahana untuk meningkatkan kualitas sumber daya manusia tersebut adalah Pendidikan hampir tidak terjamah.

SDM yang terbaik diciptakan melalui proses Pendidikan. Sekolah merupakan tempat mengenyam Pendidikan yang paling ampuh. Sebagai suatu tempat mengalirnya berbagai ilmu pengetahuan tentu memiliki visi, misi, tujuan dan fungsi. Untuk mewujudkan visi dan misi, mencapai tujuan, serta menjalankan fungsinya sekolah memerlukan SDM profesional, system tata Pamong yang baik serta segala sumber yang mendukung baik finansial maupun non finansial.

Pendidikan merupakan sebuah filter untuk menumbuh kembangkan potensi sumber daya manusia. Undang-undang Sistem Pendidikan Nasional menjelaskan, bahwa tujuan pendidikan nasional adalah mengembangkan Sumber Daya Manusia Indonesia seutuhnya yaitu SDM yang menjunjung tinggi nilainilai relegius, menjadi sumber inspirasi, serta motivasi dalam berbagai kegiatan kemasyarakatan dan kebangsaan nasional Indonesia (UU Sisdiknas, 2003).
Untuk mewujudkan fungsi dan tujuan pendidikan nasional seperti di atas maka diperlukan adanya guru, kepala sekolah, dan pegawai kependidikan yang profesional. Sejalan dengan era desentralisasi dan otonomi khusus daerah, pemerintah daerah diharapkan mampu meningkatkan mutu sekolah di daerahnya. Dengan demikian peranan kepala sekolah sangat berpengaruh dalam mengenali kebutuhan dan kemampuan yang ada dalam sekolah. school-based management atau manajemen berbasis sekolah hadir sebagai ide baru dalam pembangunan pendidikan yang berorientasi pada kebutuhan sekolah.

Menurut Menon (2002) sebuah organisasi akan berhasil jika dipimpin oleh seorang pemimpin yang berintegritas. Oleh karena itu keberhasilan atau kegagalan suatu organisasi baik yang berorientasi bisnis maupun publik, tentu seiring dengan keberhasilan atau kegagalan Leader. Pemimpin yang besar awalnya harus menjadi pelayan para bawahannya. Pemimpin harus memiliki impian besar melihat masalah sebuah organisasi baik itu dari perspektif konseptual organisasi publik.

Fenomena sebuah organisasi publik, bahwasannya pimpinan selalu membuat ketergantungan yang dipimpinnya. Apabila pimpinan tidak memiliki kemampuan untuk memimpin, maka tugas-tugas yang sangat kompleks tidak dapat terselesaikan dengan baik. Sejalan dengan Teori yang dijelaskan oleh Gibson et al (2006) bahwa Kepemimpinan didefinisikan sebagai usaha seorang person dalam 
mempengaruhi baik langsung dan tidak langsung sehingga Person yang dipimpin akan termotivasi untuk bekerja sama mencapai visi organisasi. Hal ini didasari pada otoritas mutlak seorang Leader dalam membuat planning, directing, coordinating, dan evaluating perilaku SDM. Pemimpin organisasi dapat mempengaruhi SDM yang dimilikinya dengan cara menciptakan sistem yang lebih spektakuler dan sesuai kebutuhan masa datang secara tidak terbatas di berbagai jenis kelompok spesifik yang berhubungan di organisasi.

Menurut Mulyasa (2011) faktor yang sangat berharga terhadap mutu pendidikan adalah kepala sekolah. Kepala sekolah merupakan pimpinan tunggal di sekolah yang mempunyai tanggung jawab untuk menjabarkan visi ke dalam misi terget mutu peserta didik.

Kepala sekolah selain dalam menjalankan tupoksinya juga mempunyai peran manajerial. Wahyudi (2009) menjelaskan tiga bidang keterampilan manajerial yang harus dikuasai oleh kepala sekolah yakni keterampilan konseptual (conceptual skill), keterampilan hubungan manusia (human skill), dan keterampilan teknik (technical skill). Ketiga keterampilan tersebut diperlukan untuk membuat keputusan serta memberikan pengarahan dan pengendalian dalam organisasi.

Sejalan dengan peran vital kepala sekolah tersebut, realitas di lapangan menunjukkan fenomena yang kurang menggembirakan. Fenomena tersebut menunjukkan masih banyaknya kepala sekolah yang kinerja optimalnya belum nampak. Hasil ini dapat ditelusuri dari mutu pendidikan yang setiap tahun cenderung stagnan dan tidak mengalami peningkatan secara signifikan yang berarti. Padahal persaingan antar individu di masa depan semakin serius, baik yang terjadi pada level lokal, regional, nasional, maupun global (Bahri, 2010).

Keberhasilan kepemimpinan seorang Kepala sekolah akan membuahkan hasil, jikalau mereka memahami keberadaan organisasi yang konsekuen dan unik. Mereka harus mampu berperan sebagai seseorang yang bertanggung jawab dalam memimpin sekolah. Kepala sekolah haruslah memahami dan menguasai peranan organisasi dan hubungan kerja sama antar individu yang berada dalam lingkup sekolah. Hal ini dibutuhkan agar sekolah berhasil dalam mencapai tujuannya. Selain itu, dengan peran tersebut pula kepala sekolah dapat membuktikan kepemimpinannya sebagai leader yang berkualitas.

Menurut Mishra et al, 1990 dalam Zaenal (2010) untuk terciptanya pemimpin yang berkualitas tinggi di perlukan sebuah Kepercayaan, dimana dalam organisasi maka komunikasi terbuka sangat mutlak diterapkan, berbagi informasi, berbagi persepsi atau perasaan, dan keterlibatan karyawan lebih besar dalam keputusankeputusan. Kepercayaan didefinisikan sebagai keyakinan seorang individu bahwa pimpinan akan bersikap melakukan tindakan yang menguntungkan bagi dirinya. Kepercayaan mengacu pada keyakinan karyawan pada organisasi dan keyakinan bahwa tindakan 
organisasinya yang utama nantinya akan meningkatkan kinerja.

Robinson (1996) dalam Zaenal (2010) menjelaskan bahwa Kepercayaan akan berpengaruh secara langsung terhadap besarnya kontribusi mereka bagi organisasi dari segi kinerja, niat untk bertahan dalam organisasional, serta perilakunya. Kepercayaan berkembang dari suatu pemahaman bersama yang didasarkan pada nilai-nilai yang bersifat esensial demi adanya sebuah kesetiaan dan komitmen karyawan.

Khan et al (2014) dalam hasil studinya menjelaskan bahwa kinerja sumber daya manusia dipengaruhi oleh komitmen organisasi. Komitmen organisasi merupakan suatu sikap karyawan yang secara langsung dihubungkan dengan keikut sertaan karyawan dan niatnya untuk tinggal dalam organisasi dan dihubungkan dengan kinerja Sumber Daya Manusia. Fenomena struktural antara individu dan organisasi tersebut akan menciptakan suatu kondisi yang menimbulkan peningkatan kinerja sumber daya manusia (Ming-Chun Tsai et al, 2010).

Luthans (2006) mendefinisikan komitmen organisasi sebagai kekuatan dalam melibatkan SDM mencapai tujuan dan nilai organisasi. Dengan komitmen yang diberikan, kinerja SDM diharapkan dapat meningkat. Lebih lanjut Luthans (2006) menjelaskan komitmen organisasi sebagai sebuah sikap yang merefleksikan loyalitas SDM kepada organisasi dan merupakan suatu proses berkelanjutan. Sikap tersebut antara lain rasa identifikasi yang tinggi, rasa ikut terlibat dan setia dalam tugas-tugas organisasi ynag berkelanjutan. Setiap SDM dalam organisasi harus memiliki komitmen yang tinggi terhadap pencapaian visi dan misi serta tujuan organisasi. Organisasi sektor publik, ikatan batin antara SDM dengan organisasi dapat dibangun dari kesamaan visi dan misi organisasi.

$\begin{array}{ccr}\text { Robbins (2008) } & \begin{array}{r}\text { menjelaskan } \\ \text { komitmen }\end{array} \\ \text { bahwa } & \text { konsep } & \text { komitmenta }\end{array}$ berkelanjutan yang kuat akan tercipta bilamana SDM terikat dengan seorang pemberi kerja hanya karena tidak ada hal lain yang lebih baik. Ikatan tersebut bukan sekedar gaji ataupun reward yang akan diberikan, namun lebih pada ikatan batin misalnya ingin menjadi abdi negara dan abdi masyarakat seutuhnya.

\section{Metode Penelitian}

$\begin{array}{cc}\text { Jenis } & \text { penelitian } \\ \text { "explanatory research". Adah }\end{array}$ penelitian yang bersifat menjelaskan, artinya penelitian yang menekankan pada hubungan antara variable penelitian dengan menguji hipotesis yang uraiannya mengandung deskripsi tetapi fokusnya terletak pada hubungan antar variable. Penelitian ini dilakukan di Distrik X Provinsi Papua Barat. Populasi adalah Guru SLTP Distrik X, Provinsi Papua barat sebanyak 100 orang.

Pengambilan sampel menggunakan teknik purposive sampling, yaitu pemilihan sampel dengan cara mengambil subjek bukan berdasarkan strata atau random. Teknik purposive sampling dilakukan dengan tujuan tertentu didasarkan atas ciri-ciri, sifat atau karakteristik tertentu (Sugiyono, 2014).

Instrumen yang digunakan dalam penelitian ini adalah kuesioner yang disebarkan kepada seluruh responden. Hasil penelitian dianalisis dengan 
menggunakan konsep Struktural Equation Model (SEM) dengan program Partial Least Square (PLS). Analisis Partial Least Square (PLS) adalah metode analisis powerful karena tidak harus mengasumsikan data dengan pengukuran tertentu, dapat diterapkan pada semua skala data, tidak membutuhkan banyak asumsi dan ukuran sampel (Ghozali, 2011).

\section{Hasil dan Pembahasan}

\section{Analisis Data dengan Partial Least Square}

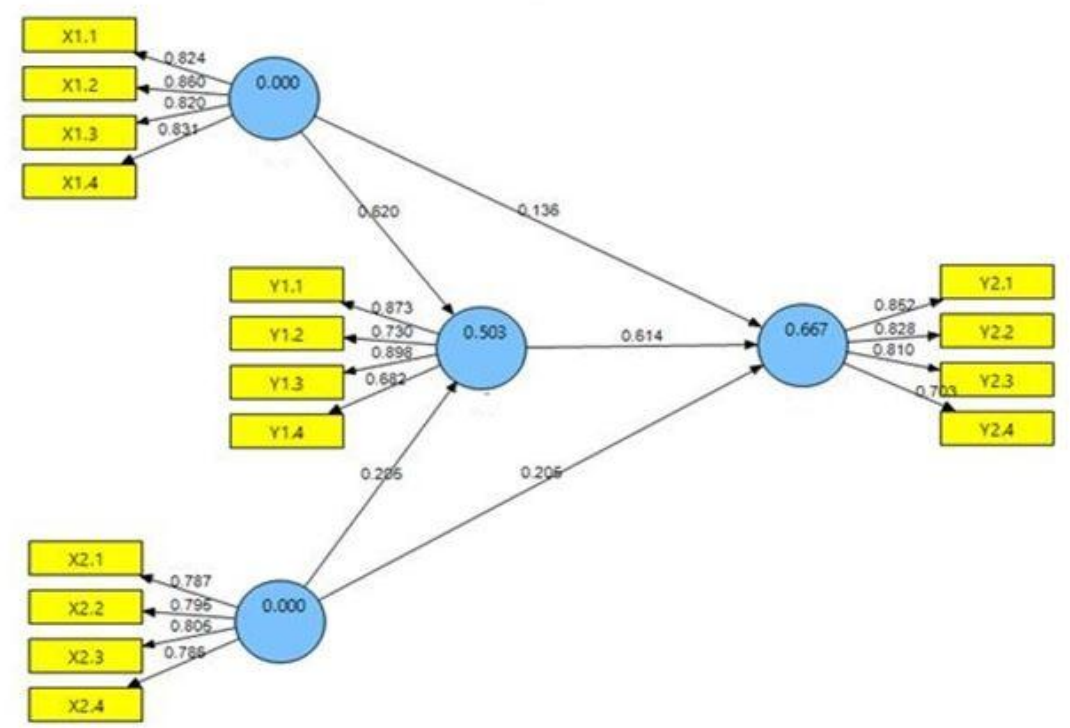

Gambar 1. Full Model Analisis

Evaluasi Measurement (Outher Model)

\section{Uji Validitas}

Uji validitas dimaksudkan untuk mengukur sah atau valid tidaknya suatu kuesioner. Suatu kuesioner dikatakan valid jika pertanyaan pada kuesioner/indikator mampu untuk mengungkapkan sesuatu yang akan diukur oleh kuesioner. Indikator penelitian dianggap valid jika mempunyai loading faktor di atas 0,5 dengan konstruk yang diukur terhadap konstruk yang dituju. Untuk menguji validitas melalui program PLS dilakukan dengan menggunakan ukuran convergent atau discriminant validity. Nilai convergent validity smartPLS memberikan nilai sebagai berikut:

Tabel 1. Result Of Outher Loading

\begin{tabular}{ccc}
\hline Indikator & $\begin{array}{c}\text { Nilai } \\
\text { Loading }\end{array}$ & $\begin{array}{c}\text { Keterang } \\
\text { an }\end{array}$ \\
\hline $\begin{array}{c}\text { Kepemimpi } \\
\text { nan }\end{array}$ & & \\
X.1.1 & 0.824468 & Valid \\
X.1.2 & 0.860370 & Valid \\
X.1.3 & 0.820140 & Valid \\
X.1.4 & 0.830675 & Valid \\
Trust & & \\
X.2.1 & 0.787331 & Valid \\
X.2.2 & 0.795073 & Valid \\
X.2.3 & 0.804689 & Valid \\
X.2.4 & 0.785635 & Valid \\
\hline
\end{tabular}




\begin{tabular}{ccc}
\hline $\begin{array}{c}\text { Komitmen } \\
\text { Normatif }\end{array}$ & & \\
Y.1.1 & 0.872645 & Valid \\
Y.1.2 & 0.729557 & Valid \\
Y.1.3 & 0.897717 & Valid \\
Y.1.4 & 0.682445 & Valid \\
Kinerja & & \\
SDM & & \\
Y.2.1 & 0.851598 & Valid \\
Y.2.2 & 0.827976 & Valid \\
Y.2.3 & 0.810188 & Valid \\
Y.2.4 & 0.702938 & Valid \\
\hline
\end{tabular}

Tabel 1 menunjukkan bahwa indikator masing - masing konstruk memberikan nilai convergent validity yang tinggi, hal ini dibuktikan dengan nilai loading yang lebih besar dari 0,5

\section{Uji Reliabilitas}

Reliabilitas suatu alat pengukur sering diartikan juga sebagai keajegan (consistency) dari alat ukur tersebut. Uji reliabilitas dilakukan dengan melihat nilai composite reliability dan nilai Square Root of Average Variance Extracted (AVE) dari indikator yang mengukur konstruk. Hasil composite reliability akan menunjukan nilai yang memuaskan jika di atas 0,7. Berikut adalah nilai composite reliability pada output :

\section{Tabel 2. Composite Reliability}

\begin{tabular}{cc}
\hline Variabel & $\begin{array}{c}\text { Composite } \\
\text { Reliability }\end{array}$ \\
\hline Kepemimpinan & 0.901380 \\
Trust & 0.876315 \\
Komitmen & 0.875921 \\
Normatif & \\
Kinerja SDM & 0.871576 \\
\hline
\end{tabular}

Tabel 2 menunjukkan bahwa nilai composite reliability diatas 0,7 . Dengan demikian seluruh variabel dalam penelitian ini dikatakan reliabel yang berarti bahwa kuesioner dalam penelitian ini dapat diandalkan untuk mengungkapkan data yang sebesarnya dari suatu obyek yang diteliti.

Selanjutnya untuk memastikan hal tersebut dapat dipastikan dengan tabel nilai Square Root of Average Variance Extracted (AVE). Nilai yang disarankan dalam hal ini adalah di atas 0,5. Berikut tabel nilai AVE:

Tabel 3. Square Root of Average Variance Extracted (AVE)

\begin{tabular}{cc}
\hline & AVE \\
\hline Kepemimpinan & 0.695659 \\
Trust & 0.640322 \\
Komitmen & 0.641347 \\
$\begin{array}{c}\text { Normatif } \\
\text { Kinerja SDM }\end{array}$ & 0.629195 \\
\hline
\end{tabular}

Tabel 3 menunjukkan bahwa nilai AVE diatas 0.5. Nilai Ave tertinggi pada variabel kepemimpinan sebesar 0.695 dan yang terendah adalah 0.629 pada konstruk variabel kinerja SDM. Kemudian konstruk lainnya variabel komitmen normatif sebesar 0.641 dan trust sebesar 0.640 sehingga dapat dinyatakan valid.

\section{Pengujian Model Struktural (Inner Model)}

Pengujian inner model atau model struktural dilakukan untuk melihat hubungan antara konstruk dengan melihat signifikansinya, dan Analisis koefisien determinasi pada $R$ - Square dari model penelitian. Model struktural dievaluasi dengan menggunakan $R$ - Square untuk mengetahui pengaruh langsung antara kepemimpinan dan trust terhadap hubungan komitmen normatif dengan kinerja SDM. 
Analisis koefisien determinasi digunakan untuk mengukur seberapa jauh kemampuan model dalam menerangkan variasi variabel dependen. Proses perhitungan dalam penelitian ini menggunakan program PLS dengan $R$-square yang dijelaskan pada Tabel 4 berikut ini:

Tabel 4. R-Square

\begin{tabular}{cc}
\hline & R Square \\
\hline Kepemimpinan & \\
Trust & 0.666788 \\
Komitmen Normatif & 0.503107 \\
Kinerja SDM & \\
\hline
\end{tabular}

Tabel 4 menunjukkan bahwa nilai $R$-square konstruk komitmen normatif sebesar 0.503107 yang berarti $50,3 \%$ variance dimensi dapat dijelaskan oleh kepemimpinan dan kinerja SDM, sisanya $49.7 \%$ dijelaskan variabel lain yang tidak termasuk dalam penelitian ini. Sedangkan nilai $R$-square konstruk trust sebesar 0.666788 yang berarti $66.6 \%$ variance trust dapat dijelaskan oleh kepemimpinan, kinerja SDM, dan komitmen normatif. Sisanya $33.4 \%$ dijelaskan oleh variabel lain yang tidak termasuk dalam penelitian ini.

\section{Pengujian Hipotesis}

Penentuan diterima atau ditolaknya suatu hipotesis dilakukan dengan membandingkan antara $t$ hitung dan t-statistik dengan menggunakan signifikansi sebesar $10 \%$ atau $0,1(1,660)$. Hasil pengujian ini dapat dilihat pada lampiran tabel $\mathrm{t}$ (distribution). Signifikansi akan dilihat dari nilai signifikansi output. Jika t statistik > t-tabel maka hipotesis diterima, jika $\mathrm{t}$ statistik $<\mathrm{t}$-tabel maka hipotesis ditolak. Uji t dapat dilihat pada result for inner weight. Keterikatan hipotesis diterima atau ditolak ditunjukkan pada Tabel 5 berikut

Tabel 5. Result for Inner Weight

\begin{tabular}{ccccc}
\hline Variable & $\begin{array}{c}\text { Original } \\
\text { Sample }\end{array}$ & $\begin{array}{c}\text { Sample } \\
\text { Mean }\end{array}$ & $\begin{array}{c}\text { Standard } \\
\text { deviation }\end{array}$ & T-Statistic \\
\hline $\begin{array}{c}\text { Kepemimpinan -> } \\
\text { Kinerja SDM }\end{array}$ & 0.136 & 0.137 & 0.040 & 3.329 \\
$\begin{array}{c}\text { Kepemimpinan-> } \\
\text { Komitmen Normatif } \\
\text { Trust-> Kinerja }\end{array}$ & 0.620 & 0.619 & 0.033 & 18.596 \\
$\begin{array}{c}\text { SDM } \\
\text { Trust -> Komitmen } \\
\quad \text { Normatif }\end{array}$ & 0.613 & 0.602 & 0.053 & 11.470 \\
$\begin{array}{c}\text { Trust -> Kinerja } \\
\text { SDM }\end{array}$ & 0.204 & 0.214 & 0.036 & 5.658 \\
\hline
\end{tabular}

\section{Hipotesis I}

Menunjukan bahwa hubungan antara variabel kepemimpinan terhadap kinerja SDM nilai $t$ statistiknya sebesar 3.329. Nilai tersebut lebih besar dari t-tabel 1,660 $(\alpha=0,1$ dan $\mathrm{df}=100)$ atau t-statistik
(3.329) > t-tabel (1,660). Hasil ini menunjukan bahwa kepemimpinan memiliki pengaruh yang positif terhadap Kinerja SDM. Hipotesis pertama yang diajukan dalam penelitian ini adalah "Kepemimpinan 
Berpengaruh terhadap Kinerja SDM "diterima.

\section{Hipotesis II}

Menunjukan bahwa hubungan antara variabel kepemimpinan dan komitmen normatif nilai t-statistiknya sebesar 18.596. Nilai tersebut lebih besar dari t-tabel 1,660 $(\alpha=0,1$ dan $\mathrm{df}=100)$ atau t-statistik $(18.596)>\mathrm{t}$ tabel $(1,660)$. Hasil ini menunjukan bahwa kepemimpinan memiliki pengaruh yang positif terhadap komitmen normatif. Hipotesis kedua yang diajukan dalam penelitian ini "Kepemimpinan Berpengaruh terhadap Komitmen Normatif “diterima.

\section{Hipotesis III}

Menunjukan bahwa hubungan antara variabel trust dan kinerja SDM nilai t-statistiknya sebesar 5.658. Nilai tersebut lebih besar dari t tabel $1,660(\alpha=0,1$ dan $d f=100)$ atau tstatistik (5.658) > t-tabel $(1,660)$. Hasil ini menunjukan bahwa trust memiliki pengaruh yang positif terhadap Kinerja SDM. Hipotesis ketiga yang diajukan dalam penelitian ini "Trust Berpengaruh terhadap Kinerja SDM “diterima.

\section{Hipotesis IV}

Menunjukan bahwa hubungan antara variabel trust dan komitmen normatif nilai t-statistiknya sebesar 4.749. Nilai tersebut lebih kecil dari ttabel 1,660 $(\alpha=0,1 \mathrm{dan} \mathrm{df}=100)$ atau tstatistik (4.749) > t-tabel $(1,660)$. Hasil ini menunjukan bahwa trust memiliki pengaruh yang positif terhadap komitmen normatif. Hipotesis keempat yang diajukan dalam penelitian ini "Trust
Berpengaruh terhadap Komitmen Normatif "diterima.

\section{Hipotesis $V$}

Menunjukan bahwa hubungan antara variabel Komitmen Normatif dan kinerja SDM nilai t-statistiknya sebesar 11.470. Nilai tersebut lebih besar dari $\mathrm{t}$ tabel 1,660 $(\alpha=0,1$ dan $\mathrm{df}=100)$ atau t-statistik $(11.470)>\mathrm{t}$ tabel $(1,660)$. Hasil ini menunjukan bahwa Komitmen Normatif memiliki pengaruh yang positif terhadap Kinerja SDM. Hipotesis kelima yang diajukan dalam penelitian ini "Komitmen Normatif Berpengaruh terhadap Kinerja SDM "diterima.

\section{Kepemimpinan berpengaruh terhadap kinerja sumber daya manusia}

Hasil pengujian hipotesis membuktikan bahwa kepemimpinan mempunyai pengaruh terhadap kinerja SDM pada guru SLTP di Distrik X. Hal Ini memiliki arti bahwa semakin tinggi intensitas penerapan kepemimpinan oleh kepala sekolah maka semakin tinggi pula tingkat kinerja SDM pada guru SLTP di Distrik X.

Hasil penelitian ini sejalan dengan penelitian yang dilakukan oleh Warigan dan Sunarto (2013), yang menemukan bahwa pengaruh langsung kepemimpinan kepala sekolah terhadap kinerja guru signifikan. Penelitian Nurwati dkk (2012), mengidentifikasikan bahwa kepemimpinan yang baik dapat meningkatkan kinerja pegawai dengan memperhatikan faktor-faktor seperti budaya organisasi, komitmen pekerjaan dan perilaku bekerja. Yeh \& Hong (2012), menemukan 
kepemimpinan positif dan signifikan mempengaruhi kinerja karyawan. Hasil tersebut mengindikasikan bahwa dengan kepemimpin yang baik mampu menumbuhkan kualitas kerja yang baik, kemampuan kerja karyawan yang baik, ketepatan waktu kerja dan kreativitas karyawan. Sehingga akan meningkatkan kinerja guru terhadap organisasi.

\section{Kepemimpinan berpengaruh signifikan terhadap komitmen normatif.}

Hasil pengujian hipotesis membuktikan bahwa kepemimpinan berpengaruh terhadap komitmen normatif. Hal ini memiliki arti bahwa semakin tinggi intensitas penerapan kepemimpinan oleh kepala sekolah, maka semakin tinggi tingkat komitmen normatif guru pada SLTP di distrik X.

Hasil penelitian ini sejalan dengan penelitian Omidifar (2013), yang meneliti hubungan antara gaya kepemimpinan kepala sekolah, komitmen organisasi dan kepuasan kerja guru SMA di Teheran. Hasil penelitian menunjukkan adanya hubungan yang positif dan signifikan antara gaya kepemimpinan terhadap komitmen organisasi. Penelitian Indayati dkk (2012) menunjukkan adanya pengaruh antara gaya kepemimpinan terhadap komitmen organisasional. Yeh \& Hong (2012) menemukan bahwa kepemimpinan positif dan signifikan mempengaruhi komitmen organisasi.

Hasil tersebut mengindikasikan bahwa dengan kepemimpinan yang baik akan mampu menumbuhkan komitmen yang kuat dari para guru terhadap organisasi mereka.
Komitmen ditandai dengan keterikatan emosional dan rasa bangga terhadap organisasi, tidak memiliki keinginan untuk meninggalkan organisasi, serta memiliki kewajiban dan tanggung jawab untuk bertahan dalam organisasi. Hal ini cocok jika diterapkan pada pada guru SLTP di distrik X, karena kebanyakan SDM di sekolah tersebut telah berusia diatas 49 tahun dan masa kerja diatas 10 tahun, serta seringnya terjadi pemutasian untuk kemajuan karir. John \& Taylor (1999) berpendapat bahwa faktor yang mempengaruhi komitmen yaitu karakteristik pribadi yang berkaitan dengan usia dan masa kerja, karakteristik struktural yaitu kemajuan karier dan peluang promosi jabatan.

\section{Trust berpengaruh terhadap kinerja sumber daya manusia}

Hasil pengujian hipotesis membuktikan bahwa trust mempunyai pengaruh terhadap kinerja SDM pada guru SLTP di distrik $X$. Hasil pengujian ini memiliki arti bahwa semakin tinggi intensitas trust maka semakin tinggi kinerja SDM pada guru pada SLTP di distrik X.

Hasil penelitian ini sejalan dengan penelitian yang di lakukan oleh Ilham (2016) yang menemukan bahwa ada hubungan yang signifikan antara tingkat kepercayaan terhadap kinerja anggota DPRD Kota Makasar.

Hasil tersebut mengindikasikan bahwa dengan trust yang baik, dapat meningatkan kualitas kerja yang baik, kemampuan kerja karyawan yang baik, ketepatan waktu bekerja dan kreativitas karyawan, sehingga akan memicu peningkatkan kinerja SDM. 


\section{Trust Berpengaruh Komitmen Normatif.}

Hasil pengujian hipotesis membuktikan bahwa trust memiliki pengaruh terhadap komitmen normatif pada guru pada SLTP di distrik X. Hal ini memiliki arti bahwa semakin tinggi intensitas trust maka semakin tinggi komitmen organisasi pada guru SLTP di distrik X.

Menurut Hadiatmojo (2012), secara umum karyawan akan termotivasi karena beberapa faktor diantaranya adalah pekerjaan yang menarik dan menantang, suasana yang memberikan trust (kepercayaan), membuat karyawan secara personal bertanggung jawab pada hasil, serta mampu tumbuh dan berkembang. Kurangnya kepercayaan dapat menimbulkan penurunan kreativitas dan gairah dalam bekerja seperti yang dikemukakan oleh Covey \& Merrill (2010). Mereka mengungkapkan bahwa kepercayaan yang tinggi berarti memperbaiki semangat, energi, gairah, kreativitas dan suka cita dalam hubungan keluarga, teman dan komunitas. Whitney dalam Covey \& Merrill (2010) berpendapat bahwa ketidakpercayaan melipatgandakan biaya berbisnis.

$$
\text { Hasil }
$$

tersebut

mengindikasikan bahwa dengan trust mampu menumbuhkan komitmen yang kuat dari para guru terhadap organisasi mereka. Keadaan ini ditandai dengan adanya keterikatan emosional dan rasa bangga terhadap organisasi, tidak memiliki keinginan untuk meninggalkan organisasi, memiliki kewajiban dan tanggung jawab untuk bertahan dalam organisasi, karyawan memiliki tanggung jawab dalam melaksanakan tugas atau pekerjaannya, sehingga akan terbentuk trust yang baik.

\section{Komitmen Normatif berpengaruh positif terhadap kinerja sumber daya manusia.}

Hasil pengujian hipotesis membuktikan bahwa komitmen normatif berpengaruh terhadap kinerja SDM. Hal ini memiliki arti bahwa semakin tinggi komitmen oleh guru maka semakin tinggi kinerja SDM pada guru SLTP di distrik X.

Hasil penelitian ini sejalan dengan penelitian Yeh et al. (2012), yang menemukan bahwa komitmen organisasi berpengaruh positif dan signifikan mempengaruhi kinerja karyawan. Hasil penelitian ini juga didukung oleh penelitian yang dilakukan Folorunso et al. (2014) dimana komitmen normatif mempunyai hubungan yang signifikan pada kinerja karyawan. Lebih lanjut penelitian yang dilakukan Khan et al. (2014) menemukan hasil yang signifikan antara komitmen normatif dengan kinerja karyawan. Rawi (2017) menjelaskan bahwa kinerja pegawai atau karyawan dapat menumbuhkan peningkatan bisnis sebuah perusahaan atau lembaga, juga menumbuhkan motivasi kerja dari karyawan.

Hasil tersebut mengindikasikan bahwa dengan komitmen normatif yang baik, menumbuhkan kualitas kerja yang baik, kemampuan kerja karyawan yang baik, ketepatan waktu bekerja dan kreativitas karyawan, sehingga akan meningkatkan kinerja SDM. 
Pengaruh Langsung dan Tidak terhadap Kinerja SDM melalui Langsung Komitmen Normatif (interviening).

Pengaruh langsung dan tidak langsung kepemimpinan dan trust

\section{Pengaruh Kepemimpinan terhadap Kinerja SDM melalui Komitmen Normatif}

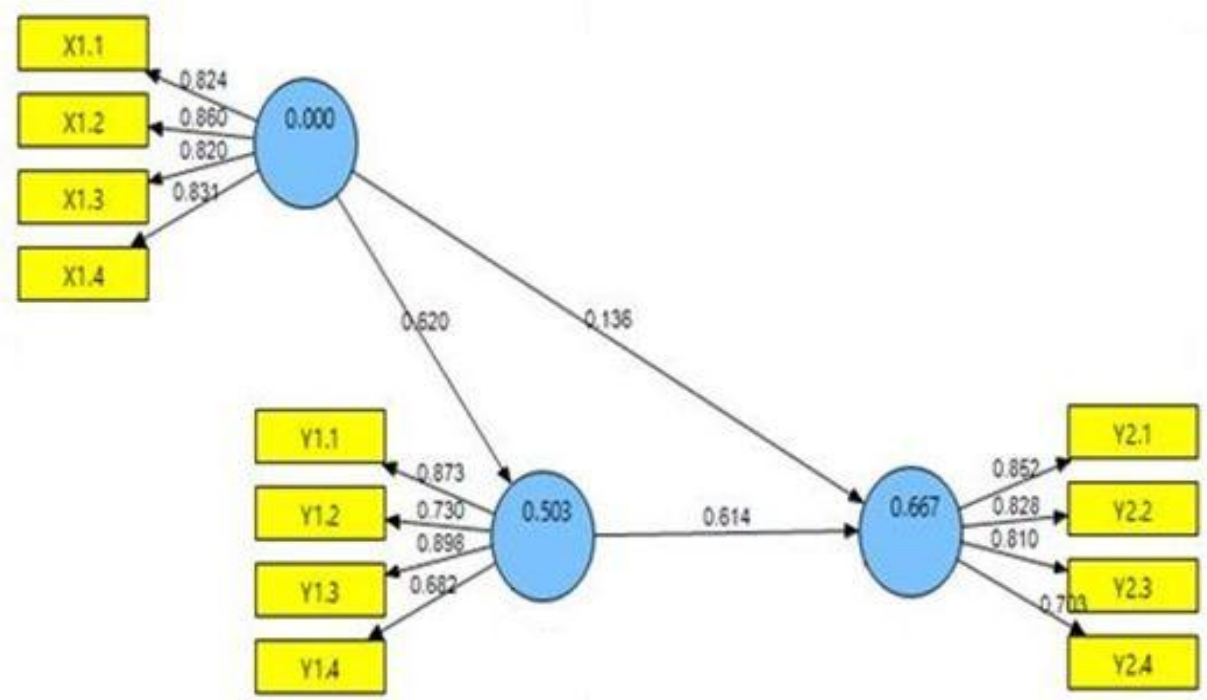

Gambar 2. Analisis jalur Kepemimpinan terhadap Kinerja SDM

Berdasarkan hasil analisis pada Gambar 2, dapat dilihat bahwa kepemimpinan dapat berpengaruh langsung ke kinerja SDM dan dapat juga berpengaruh tidak langsung terhadap kinerja SDM melalui komitmen normatif (intervening). Besarnya pengaruh langsung adalah 0,316 sedangkan pengaruh tidak langsungnya $(0,620) \times(0,614)=$ 0,380 . Dengan demikian maka disimpulkan bahwa nilai pengaruh langsung lebih kecil dari pada pengaruh tidak langsung artinya komitmen normatif dapat memberikan mediasi hubungan kepemimpinan ke kinerja SDM.

Pengaruh Trust terhadap Kinerja SDM melalui Komitmen Normatif

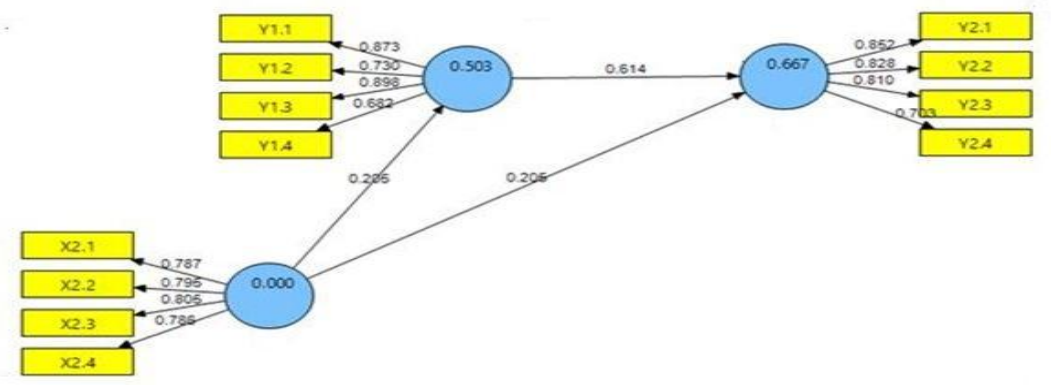

Gambar 3. Analisis Jalur Trust terhadap Kinerja SDM 
Berdasarkan hasil analisis pada Gambar 3, dapat terlihat bahwa trust dapat berpengaruh langsung pada kinerja SDM dan dapat pula berpengaruh tidak langsung terhadap kinerja SDM melalui komitmen normatif (intervening). Besarnya pengaruh langsung adalah 0,205 sedangkan pengaruh tidak langsungnya $(0,205) \times(0,614)=$ 0,125 . Dengan demikian, dapat disimpulkan bahwa nilai pengaruh langsung lebih besar dari pada pengaruh tidak langsung. Artinya komitmen normatif tidak dapat memberikan mediasi hubungan trust terhadap kinerja SDM.

\section{Kesimpulan}

Adapun kesimpulan yang dapat ditarik dari hasil penelitian ini adalah sebagai berikut:

1. Kepemimpinan berpengaruh positif terhadap kinerja sumber daya manusia. Artinya, semakin tinggi kepemimpinan maka semakin meningkatkan kinerja sumber daya manusia.

2. Kepemimpinan berpengaruh positif terhadap komitmen normatif. Artinya, semakin tinggi kepemimpinan maka semakin meningkatkan Komitmen normatif.

3. Trust berpengaruh positif terhadap kinerja sumber daya manusia. Artinya, semakin tinggi trust maka semakin meningkat kinerja sumber daya manusia.

4. Trust berpengaruh positif terhadap komitmen normatif. Artinya semakin tinggi trust maka semakin meningkat Komitmen Normatif.

5. Komitmen normatif berpengaruh positif terhadap kinerja sumber daya manusia. Artinya semakin tinggi komitmen normatif maka semakin meningkat kinerja sumber daya manusia.

\section{Saran}

1. Kepemimpinan, Trust, dan komitmen normatif perlu ditingkatkan pada guru di SLTP Distrik "X", demi tercapainya peningkatan kinerja sumber daya manusia pada sekolah tersebut.

\section{DAFTAR PUSTAKA}

Bahri, S. 2010. Optimalisasi Kinerja Kepala sekolah, Gibon Books, Jakarta.

Covey, S. M. R., \& Merrill, R. R. (2010). The speed of trust: Satu hal yang mampu mengubah segalanya. Tangerang Selatan: Karisma Publishing Group.

E. Mulyasa, 2011. Manajemen dan Kepemimpinan Kepala Sekolah, Bumi Aksara, Jakarta.

Folorunso, O.O, Adewale, A. J. Abodunde, S.M. 2014. Exploring the Effect of Organizational Commitment Dimensions on Employees Performance: An Empirical Evidence from Academic Staff of Oyo State Owned Tertiary Institutions, Nigeria. International Journal of Academic Research in Business and Social Sciences. Vol. 4, No. 8.pp.275-285.

Gibson, James L et al 2006. Organizations (Behavior, Structure, Processes), 
Twelfth Edition, McGrow Hill.

Hadiatmojo, S. 2012.Impact (Innermotivation \& performance action). Jakarta: Elex Media Komputindo

Ilham .2016. Hubungan antara tingkat kepercayaan dengan kepuasan masyarakat terhadap kinerja anggota DPRD Kota makassar. Universitas Negeri Makassar. Volume XI Nomor 2, Oktober 2016.

Imam Ghozali, 2011. Metode Alternatif dengan Partial Least Square (PLS). Badan Penerbit UNDIP, Semarang.

Indayati, N, Thoyib, A dan Rofiaty, 2012. Pengaruh Keterlibatan Karyawan, dan gaya Kepemimpinan terhadap Komitmen Organisasi dalam Meningkatkan Kinerja Karyawan (Studi pada Universitas Brawijaya); Jurnal Aplikasi Manajemen Volume 10 Nomor1 Maret 2012.

John, M.C. and Taylor, J.W. 1999. Leadership Style School Climate, and The Institutional Commitment of Teacher. International Forums, Vol. 2, No.1, pp 25-57

Khan, Irfanullah. Allah Nawaz. Shadiullah Khan. Farhatullah Khan, Saqib Khan and Naseem Bakht Yar. 2014. The Impact of Organizational Commitment (Oc) On the Intention To Leave (Itl) Among The Academicians
In Higher Educational Institutions (Heis) In Pakistan.

International Journal of Academic Research in Business and Social Sciences. Vol. 4, No. 2.

Luthans, F. 2006. Perilaku Organisasi Edisi Sepuluh.Yogyakarta, Penerbit Andi.

Menon, Maria E. 2002," Perceptions of Pre-Service and In-Service TeachersRegarding The Effectiveness of Elementary School Leadership in Cyprus", The International Journal of Educational Management, 16 February, 91-97.

Nurwati, Umar Nimran, Margono Setiwan dan Surachman, $2012 . \quad$ Pengaruh Kepemimpinan Terhadap Budaya Organisasi, Komitmen Kerja, Prilaku kerja dan Kinerja Pegawai (Studi Pada Satuan Perangkat Daerah Propinsi Sulawesi Tenggara); Jurnal Aplikasi Manajemen Volume 10 Nomor1 Maret 2012.

Omidifar, R. 2013. Leadership Style, Organizational Commitment and Job Satisfaction: A Case Study on High School Principals in Tehran, Iran. American Journal of Humanities and Social Sciences Vol. 1, No. 4, 2013, PP 263-267

Rawi, R. D. P. (2017). Analisis Hubungan Motivasi Terhadap 
Model Peningkatan Kinerja Sumber Daya Manussia ...

Reijeng Tabara

Kinerja Pegawai (Studi Kasus Pada Kantor Kecamatan Ruing Kabupaten Ngada Ntt). Jurnal Noken: Ilmu-Ilmu Sosial, 2(2), 15-28.

Robbins dan Judge, 2008. Perilaku Organisasi Edisi 2. Jakarta: Salemba Empat

Sugiyono. 2014. Statistika untuk Penelitian. Bandung: Alfabeta.

Tsai, Ming Chun. Ching-Chan Cheng and Ya-Yuan Chang. 2010. Drivers of Hospitality Industry Employees' Job Satisfaction, Organizational Commitment and Job Performance. Journal of Business Management. Vol. 4(18), pp. 4118-4134.

Undang-Undang Republik Indonesia Nomor 20 Tahun 2003, edisi 2009, Sistem Pendidikan Nasional, Depdiknas. Bandung, Citra Umbara.

Wahyudi, 2009. Kepemimpinan Kepala Sekolah dalam Organisasi Pembelajar. Jakarta, Alfabeta.

Warigan, S dan Sunarto 2013. "Pengaruh Determinan Kinerja Guru SMK BidangKeahlian Tehnik Mesin. Jurnal Penelitian dan Evaluasi Pendidikan Tahun 17, Nomor 1.

Yeh, H. \& Hong, D. 2012. The Mediating Effect of Organizational commitment on Leadership Type and Job
Performance. The Journal of Human Resource and Adult Learning, V 50 ol. 8, Num. 2, December 2012, PP 50-59.

Zaenal dkk .2010. Pengaruh karakteristik individu, stress kerja, kepercayaan organisasional terhadap intention to stay melalui kepuasan kerja dan komitmen organisasional. Universitas Brawijaya Malang. ISSN 1693-1541. 